\title{
CONTROVERSIES REGARDING THE INTERPRETATION OF THE EXCHANGE RATE REGULATION IN THE MEAT PRODUCTION ACTIVITY
}

\author{
https://doi.org/10.47743/jopafl-2021-21-06
}

\author{
Teodora PASERE \\ Alexandru Ioan Cuza University of Iași, Faculty of Economics and Business \\ Administration, \\ Iaşi, România \\ teodora.pasere@gmail.com
}

\begin{abstract}
In the context of contemporary food security concerns, commercial transactions involving live animals have increased significantly. This document critically analyzes the controversies regarding the accounting records of the exchange rate used at the date of receipt of biological assets such as stocks as a result of intra-community commercial acquisition operations. We consider that the legal document Letter of Consignment or the International Covenant on Transport Contracts (C.M.R.) on the basis of which the goods are received and the entry into administration is assigned to account 408 "Suppliers-incoming invoices", and the favorable / unfavorable exchange rate difference at the subsequent arrival of INVOICE is in return for account 408 "Suppliers- incoming invoices". Incorrect accounting registration of INVOICE only through account 401 "Suppliers" is contrary to the accounting regulations of Order no.1802/2014, because the goods were received by C.M.R. prior to the arrival of INVOICE, thus giving rise to the calculation of favorable / unfavorable exchange rate differences with fiscal and financial influences.

Keywords: Conforming accounting regulations, relevance, exact representation, legal form of the document, economic nature of the operation, professional reasoning

This Article was presented as a paper at the $13^{\text {th }}$ edition of the Annual International Conference Globalization and Higher Education in Economics and Business Administration (GEBA 2021), which was held at the Alexandru Ioan Cuza University, Faculty of Economics and Business Administration in Iasi, Romania from the $21^{\text {st }}$ to $23^{\text {rd }}$ of October 2021.
\end{abstract}

\section{Introduction}

From 1990 to 2020, the share of the breeding activity of pigs (swine) like other animal branches in Romania, registered a strong decline. Thus , the swine herds in 2003 (5145448 heads) represented 42,86\% of the herds of 1990 (12003470 heads). The herds as the first May 2020 (3669342 heads) represented only 30,56 \% of the swine herds of 1990. As a result, in order to cover its pork needs, Romania makes intra-Community aquisitions of biological assets of the nature of stocks. Romanian businessmen purchase intraCommunity swine and carry out the production of pork through weight gain. The increase in weight gain is determined monthly, and at 90 days the capitalization of the swine is made, by sale. 


\section{Preliminary notions}

C.M.R.is a document with special regime, of road freight transport, drawn up on the basis of a transport contract (concluded between the consignor/supplier and the carrier). It is used in the transport of goods between two countries. It shall be drawn up in three originals copies. it is signed by the sender/supplier and carrier.The first copy shall be given to the consignor/supplier, the second copy shall accompany the goods and the third copy shall be returned to the carrier. When the goods to be transported have to be loaded into more than one vehicle, separate waybills shall be drawn up for each vehicle.All these transport letters will be entered in the INVOICE that will arrive later. The number, series and date C.M.R. can be found later inserted in invoice. "Avizul de însoțire a mărfii" is a document used on the territory of Romania, which accompanies the goods during transport. It is not used in the carriage of goods by road, between two countries. The " Notice accompanying the goods" cannot replace C.M.R. The notice accompanying the goods is a financial-accounting document on the basis of which accounting entries can be made, without the fact that it is mandatory to draw up the invoice. At the same time, this financial accounting document is the basis for the transfer of material values, from one management to another territorially dispersed, in Romania, belonging to the same economic entity, in which case it will be entered "without invoice". The mention "For processing to third parties" where there are material values sent for processing to third part. In other situations, other than those presented above, the cause for which the Notice accompanying the goods was drawn up will be maintained and not the invoice.

Invoice is a supporting document on the basis of which economic transactions are recorded in the accounts. At the same time, it is also a document that includes tax information, such as: the taxable base, the nature of the goods supplies or supplies of goods, the possible VAT rates, mentions regarding the transactions. For the purposes of Directive 112_2006 as amended and supplemented, the concept of invoice states that documents and messages shall be accepted between Member States in paper or electronic form as invoices meeting the conditions. The invoice has the following details, important from a fiscal point of view, for VAT purposes:the date of issue; a squential number based on series, the VAT identification number on the basis of which the taxable person has delivered/ supplied the services; the VAT identification number of the customer on the basis of whom the customer has benefited from a supply of goods or services for which he is liable to pay VAT or has benefited from supply of goods; the full name and address of the taxable person and the customer; the quantity and nature of the goods delivered or the volume and nature of the services provided; the date on which the supplies of goods or services were effected or concluded, possibly the date on which the advance was paid; the taxable base for each quota (for biological assets of the nature of stocks-piglets, the VAT rate in Romania according to the Fiscal Code is 9\%); the VAT rate applied; the amount of VAT to be paid, unless a special scheme applies for which Directive 112_2006 excludes the mention. From a fiscal point of view, the content of the EU Directive includes simplification measures, declarations, recapitulative statements, special regimes, derogations. We can talk about a classification of invoices:

- electronic invoice is the document or message that has been issued and received in any electronic format, issued by a taxable person, 
- simplified invoice is a document or message that has been issued and received, in paper or electronic form, less than 100 Eur or the equivalent in national currency.

\section{Case study}

The accounting regulations on the individual annual financial statements and consolidated financial statements (Order of the Minister of Finance no.1802 of 29 December 2014, as subsequently amended and supplemented), which originate in Directive 2013/34 EU of the European Parliament and of the Council also include the development of the detailed general chart of accounts in the classes of accounts, groups of accounts and synthetic accounts of the first degree and synthetic accounts of the second degree. In the form of presentation of the balance sheet, the horizontal form, in letter B. Current assets we have at figure I Stocks with the items carried out, as follows:

'B. Current assets

I. Stocks

1. Raw materials and consumables

2. Production in progress

3. Finished products and goods

4. Advances" (Section 4.2 of Order no.1802/2014).

A Romanian entrepreneur has concluded a contract for the purchase of piglets (swine) with a supplier in the Netherlands. The commercial transactions are carried out between two partners from two different countries, territorially distanced, EU member states. The purchase contract is carried out for a period longer than 6 months. The road transport contract is carried out with specially equipped machines for the transport of live swine and is a contract concluded between the supplier and the transport company. The invoice is issued after a few days, after the carrier arrives at the supplier. The Romanian economic entity makes the purchase of swine from an EU member state, the purchase price being established by the purchase contract, in Euro currency. The transport is carried out by special means of transport for the transport of swine, based on the C.M.R., and the duration of the transport is in days. Before carrying out the transport, the supplier sends a Pro-Invoice to the Romanian economic entity. The cost of transportation is the responsibility of the supplier of swine.

In the following, we will analyze the accounting records generated by the activity of intra-Community acquisition of swine for the purpose of meat production, carried out by the economic entity with Romanian private capital. The Romanian entity focuses on obtaining and recording the accounting of the "weight gain", as a production process in animal husbandry.

In this article, the following accounting accounts will be used:

$\rightarrow$ Account 361 " Biological assets in the nature of stocks ", an element with a patrimonial asset substance,

$\rightarrow$ account 408 " "Suppliers - incoming invoices", element with patrimonial passive substance,

$\rightarrow$ Account 711 'Revenue for the cost of stocks of products', a liability substance item,

$\rightarrow$ Account 606 'Expenditure on biological assets of a stock nature', an item with an active substance,

$\rightarrow$ contul 401'Suppliers', item with a patrimonial passive substance, 
$\rightarrow$ Account $665^{\prime}$ Expenses from exchange rate differences expressed in foreign currency', asset substance item, first degree synthetic account,

$\rightarrow$ account 7651" Favourable exchange rate differences related to monetary items denominated in foreign currency", item with liability substance, synthetic account of the second degree,

The accounting method used in the accounting management of "Biological assets of the nature of stocks" is the method of permanent inventory, recording all entry and exit operations both in quantity and value, at any time being known the stocks and their value. In Section 4.6, "Third parties" of the Order of the Minister of Public Finances no. No 1802/2014 in paragraph 314(4) I have the following description, I quote:

'4. In the case of goods acquired accompanied by the invoice or the notice accompanying the goods, and the invoice will arrive subsequently, the exchange rate used for entry in the accounts shall be the rate at the time of receipt of the goods.'

The case of the intra-Community acquisition of swine described above does not, primacy, fall within the scope of point 314(4) of that order. It is a legislative loophole that generates errors of interpretation and accounting registration, including in accounting software and, through tax fines. In the author's opinion, the accounting records generated by the intra-Community acquisition of biological assets of the nature of stocks - swine, must be recorded as follows:

1. On June 2, 2021, the transport of piglets (1244 heads* 86,4926 Eur/cap= 107,596,82 Eur; 1244 heads * 25kg= $30600 \mathrm{~kg}$ ) is received, based on C.M.R., the exchange rate being 4.9197 lei/ 1eur:

361.01

$=408$ "Suppliers - incoming invoices"

529,344.08 lei

"Biological assets of a stock nature"

analytically young swine

The Entry Note Reception of swine is made on the basis of C.M.R. which is a document of transport and accompanying of the intra-Community goods. The C.M.R. is the basis for the preparation of the INVOICE, subsequently.

2. On 07.06.2021, the arrival of INVOICE from the swine supplier is recorded, the invoice value of 107,596.82 Eur, the exchange rate being 4.9230 lei / 1eur. At the same time, we also record the reverse charge with the simplified rate of 9\% (art. 291 paragraph (2) letter e) of the Fiscal Code. We have the following records in accounting:

408 "Suppliers - incoming invoices" = 401 "Suppliers"

$529,699.14$ lei

4426"VAT deductible" = = $\quad$ = $=2427$ "VAT collected"

$47,672.92$

lei

3. It was calculated an unfavorable exchange rate difference of 355.06 lei recorded by debit of the account 665 "Expenses from exchange rate differences expressed in foreign currency", "and crediting the account 408 "Suppliers - unseasy invoices":

$665=408$ "Suppliers - incoming invoices"

355.06 lei

"Expenses from exchange rate differences expressed in foreign currency " 
4. The transport of piglets is received (1479 heads $* 86.4926$ Eur / head $=127.922,55$ eurEur; 1479 heads $* 25 \mathrm{~kg}=36975 \mathrm{~kg}$ ) on June 8, 2021, based on CMR, the exchange rate is 4.9229 lei / 1 eur:

$629,749.92$ lei

$361.01 \quad=\quad 408$ "Suppliers - incoming invoices"

"Inventory biological assets" analytical pig youth

5. The arrival of INVOICE from the pig supplier is registered, on 14.06.2021, the value of INVOICE 127,922.55Eur, the exchange rate is 4.9188 lei / 1 eur. At the same time, we also register the reverse charge with the simplified quota of 9\% (art. 291 paragraph (2) letter e) of the Fiscal Code. We have the following records in accounting:

408 "Suppliers - incoming invoices"= = $629,225.43$ lei

4426 ”T.V.A. deductible $56,630.28$ lei

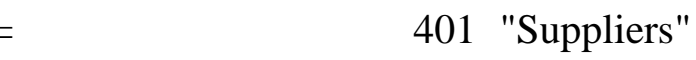

$=\quad 4427 ”$ T.V.A. collected ”

6. Calculate a favorable exchange rate difference of 524.49 lei registered through the debit of account 408 "Suppliers - unpaid invoices" and crediting of account 7651 "Favorable exchange rate differences related to monetary items expressed in foreign currency":

408 "Suppliers - incoming invoices" = 7651 "Favorable exchange rate differences 524.49 lei

foreign currency "

related to monetary items denominated in

In the literature and in common practice, the acquisition of biological assets in the nature of stocks was treated as follows:

1. Acquisition of biological assets

$\begin{array}{cc}404 \text { "Suppliers of fixed assets" } & 29,430 \text { lei } \\ 217 & 27,000 \text { lei }\end{array}$

"Biological assets productive”

4426

2,430 lei

"Deductible VAT"

2. In a specialized correspondence with the person in charge of maintaining the WinMentor accounting program, in the answer regarding the registration of the favorable / unfavorable exchange rate difference at the time of INVOICE arrival, after the C.M.R.

$\begin{array}{llrr}408 & = & 404 & 5,862.18 \text { lei } \\ 4426 & = & 4428 & 935.98 \text { lei } \\ 4426 & = & 404 & 0.15 \text { lei } \\ 665 & = & 404 & 0.80 \text { lei }\end{array}$

3. It is a habit to register in the accounting when the INVOICE arrives and not at the time of the arrival of the pigs with the C.M.R.ul.This is because the users of Winmentor accounting programs do not use the closure of the account 408"Suppliers- unsupersonable 
invoices" through the accounts of favorable / unfavorable differences, but in correspondence with the account 401 "Suppliers".

The road freight transport document/ the C.M.R. consignment note, on paper, has a negative impact on the environment. In the near future, the use of the e-CMR electronic consignment note will be generalized.

\section{Conclusions}

In the current contemporary conditions, 2021, Romania has lost its industrialized pork production. In 2020, May 1st, Romania's swine production is $30.56 \%$ of the swine herds of 1990. This information is statistical data. Romania achieves the production of swine through the intra-Community acquisition of piglets, on which it then achieves the "weight gain increase". Entries in the accounts regarding the acquisition of biological assets of the nature of live animal stocks intended for meat production, are made on the basis of C.M.R. (from an accounting point of view, the performance of the economic and financial operation is proved by any document in which it is recorded) by crediting the account 408"Suppliers-invoices unseated" and debiting the account 361.01 "Biological assets of the nature of stocks" analytically young swine. Upon arrival (invoice) the account 408"Suppliers-invoices unseased" is debited by crediting the account 401 "Suppliers". the account 408"Suppliers- unseased invoices" is debited by crediting the account 401 "Suppliers". Since the transaction is made in the currency of the supplier's country, from the Netherlands, we have euro. The result is the registration in the account of favorable exchange rate differences (account 765)/ unfavorable (account 665) in correspondence with the account 408" Suppliers- invoices unseased". The transaction in euro shall be initially registered at the exchange rate, communicated by the National Bank of Romania, from the date of receipt of biological assets of the nature of stocks (entry into management). Accounting is a science, it is the coded language of the accounts with which we create the life of the economic entity, through the filter of our own professional reasoning. Looking at it from another angle, accounting describes the life of the entity through its own interpretation of the matrix of professional reasoning.

\section{References}

1. INSSE,2021, statistici.insse.ro:8077/tempo-online/\#pages/tables/insse-table

2. Convention on the Contract for the International carriage of Goods by Road (CMR),1956,Geneva, United Nations

3. Ordinul ministrului finanțelor publice nr. 2634/2015 privind documentele financiar - contabile,

4. Ordinul ministrului finanțelor publice nr. 2634/2015, Anexa 1, A. Aspecte generale, punct 25 alineat 2,

5. Ordinul ministrului finanțelor publice nr. 2634/2015,Anexa I, Grupa a III-a Bunuri de natura stocurilor,

6. Ordinul ministrului finanțelor publice nr. 2634/2015, Anexa 1, A.Aspecte generale, punct 25 alineat 1,

7. Directive 112_2006, article 218, Title XI, Chapter 3 Section 2,

8. Ordinul nr. 1802/2014 published in M.O., Part I number 963 from 30 december 2014,

9. Mateș,D, 2017 Particularities regarding the organization of accounting in agriculture, C.E.C.C.A.R. BUSINESS MAGAZINE NR.45-46,

10. Convention on the Contract for the International carriage of Goods by Road (CMR),1956,Geneva, United Nation 


\section{ANNEX - THE EVOLUTION OF THE LEU-EURO EXCHANGE RATE DURING THE ANALYZED PERIOD}

The evolution of the exchange rate, the exchange ratio between the Leu and the Euro in the period 01 June 2021 to 30 September 2021. The daily dynamics, rendered in graphical form, monthly, of the comparative currency evolution

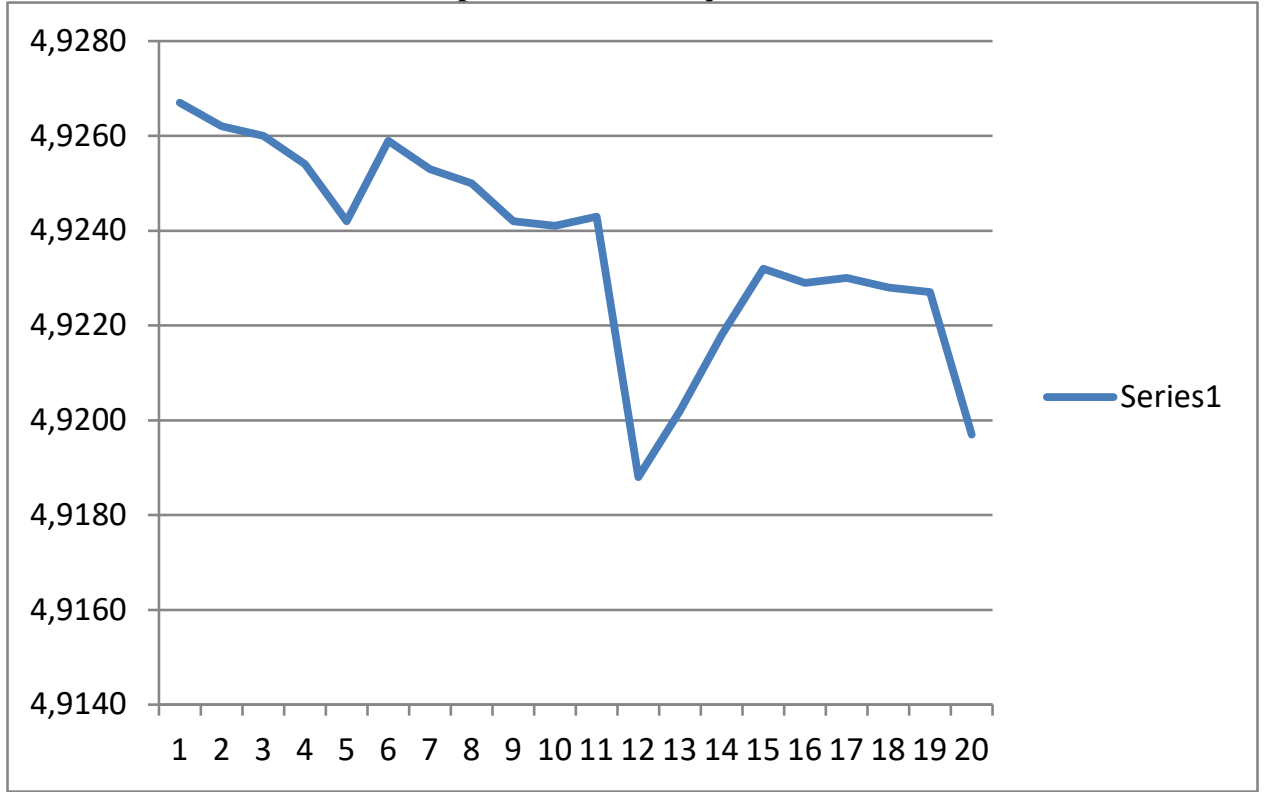

sursa https://www.bnr.ro/Raport-statistic-606.aspx 02 June 2021- 30 June 2021

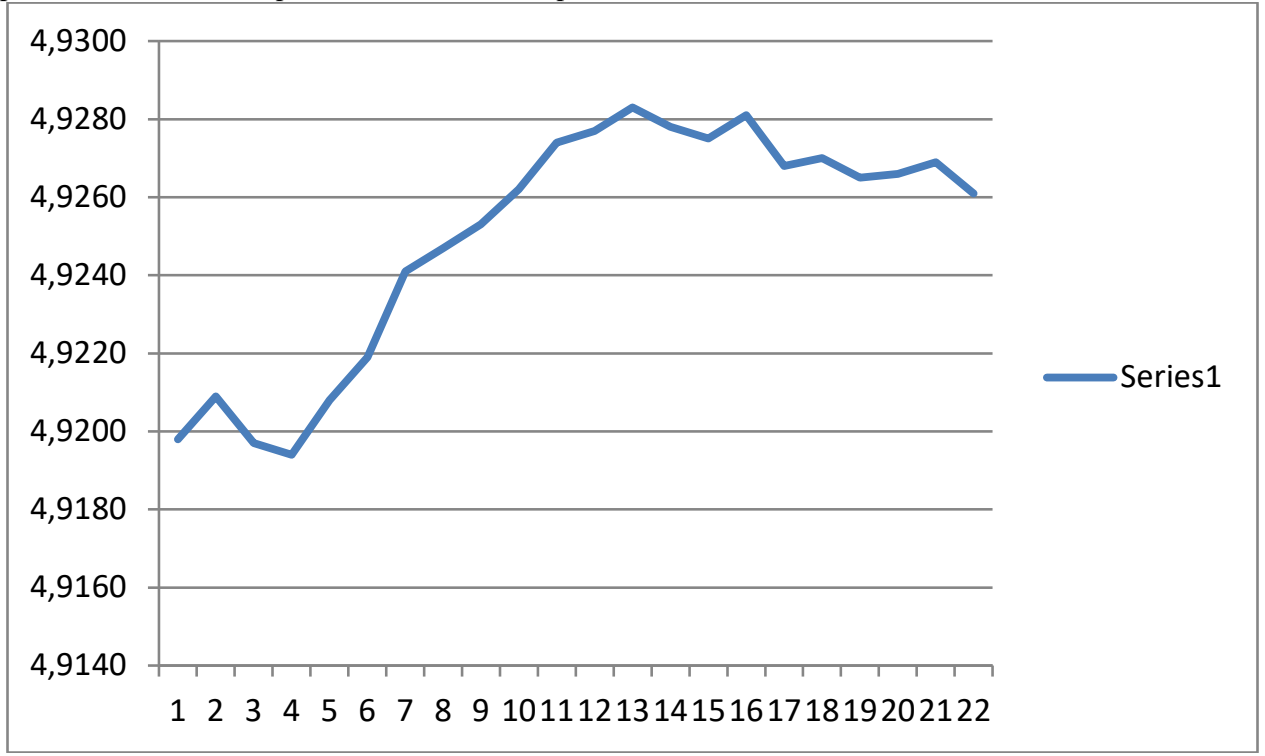

sursa https://www.bnr.ro/Raport-statistic-606.aspx 01 July 2021 until 30 July 2021 


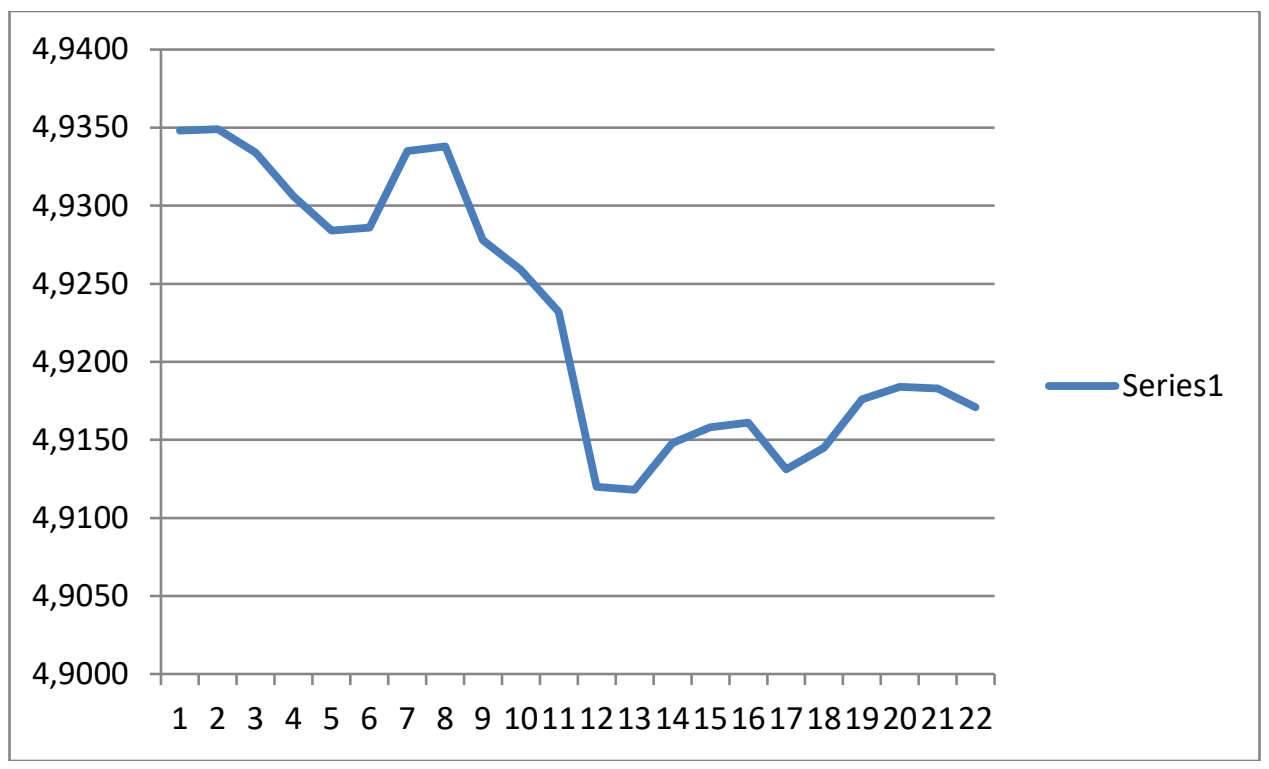

sursa https://www.bnr.ro/Raport-statistic-606.aspx 02 August 2021- 31 August 2021

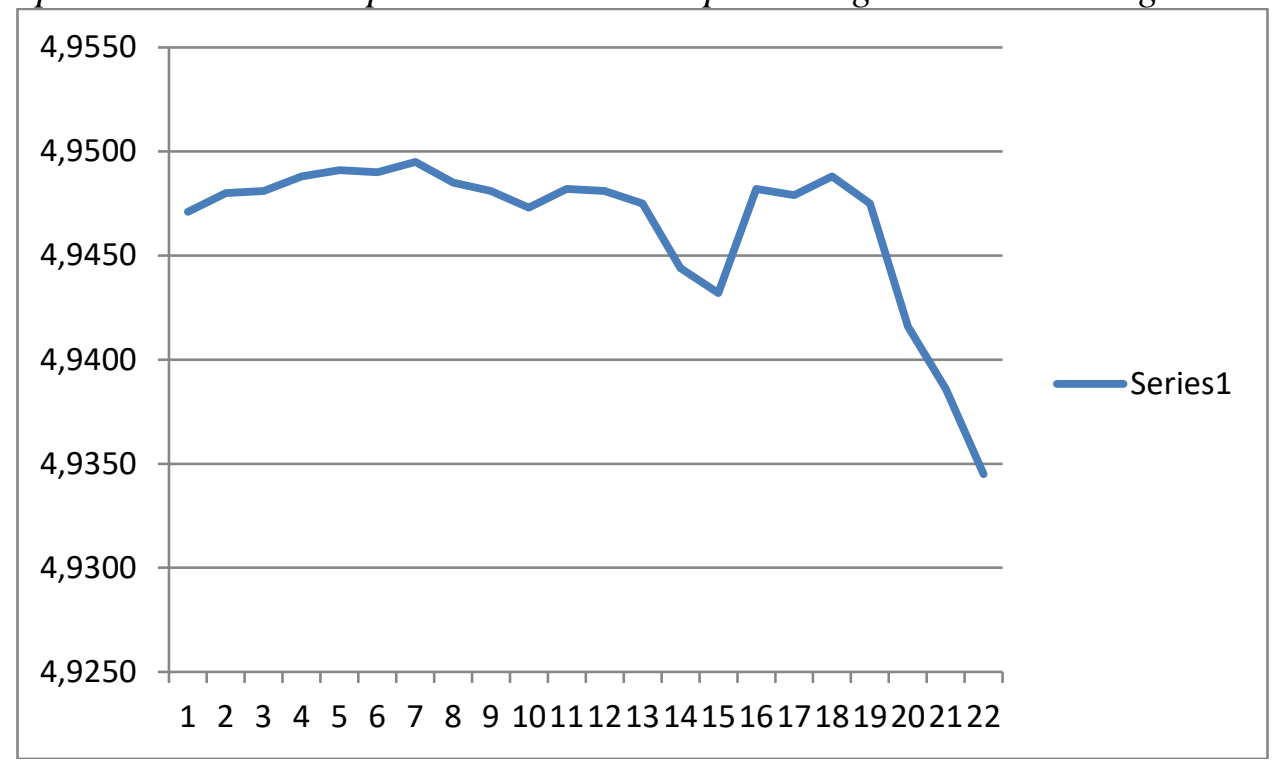
Creative Commons Attribution - Non Commercial - No Derivatives 4.0 International License. 